\title{
LA PERSISTENCIA DEL MODELO DE ASISTENCIA Y PROMOCIÓN. LA ASISTENCIA SOCIAL EN ROSARIO (2003-2013)
}

\author{
Melisa Campana $(\cdot)$ \\ Universidad Nacional de Rosario, CONICET \\ (Argentina)
}

\section{RESUMEN}

El presente trabajo analiza la gestión de la asistencia en el Municipio de Rosario, Argentina, durante la última década y tiene por objetivo mostrar la persistencia del modelo de asistencia y promoción, sosteniendo como hipótesis general que los cambios acaecidos en la estructura social nacional y local en el pasado decenio no han sido acompañados por modificaciones sustanciales en la forma de concebir los problemas y en la consiguiente lógica de intervención social del Estado municipal.

\section{PALABRAS CLAVE:}

asistencia, promoción, pobreza, problemas sociales.

\section{ABSTRACT}

This paper discusses the management of the assistance in Rosario City Hall, Argentina, during the last decade and aims to show the persistence of assistance and promotion model, holding as a general hypothesis that changes in the national and local social structure in the past decade have not been accompanied by substantial changes in the way of conceiving problems and the logic of social intervention by the municipal State.

\section{KEY WORDS:}

assistance, promotion, poverty, social problems.

\footnotetext{
(•) E-mail: melisacampana@gmail.com
} 